\title{
THEORY AND METHODS OF MEANS AND MODES SELECTION OF AGRICULTURAL EQUIPMENT SPARE PART QUALITY CONTROL
}

\author{
Dmitry Skorokhodov, Konstantin Krasnyashchikh, \\ Sergey Kazantsev, Alexander Anisimov \\ Russian Timiryazev State Agrarian University, Russia \\ kspts@bk.ru
}

\begin{abstract}
One of the most expensive aspects of agricultural machinery operation is the provision of spare parts. In order to reduce the costs, a lot of agricultural manufacturers purchase spare parts produced by alternative manufacturers, products of which often do not correlate with the official manufacturer's product quality. There is also a significant part of counterfeit products on the market. Various sources estimate it from 9 to $30 \%$ of total sales, depending on the type of spare parts. In order to reduce the supply of low-quality spare parts, organization of the spare part quality control system by the dealer side is suggested. The aim of the study is the rationalization of the techniques and quality control regimes of agricultural machinery spare part choice. Based on an experiment conducted among large number of spare part suppliers, the structure of controlled parameters of spare parts is identified. The relationship between the number of measurements, the probability of detecting defects and other probabilistic parameters for controlling the spare part quality is revealed. The authors suggest the methods of the measurement device choice from the wide variety of contact and non-contact tools used for spare part control. The functions for the determining of the quality control modes, while ensuring the greatest probability of detecting defects and the greatest productivity, are described. The comparison between the technological parameters of various measuring instruments was made.
\end{abstract}

Keywords: quality, control, spare parts, measurement, inventory management, forecasting, service maintenance.

\section{Introduction}

One of the most costly aspects of agricultural machinery operation is the spare part provision. The need for them rises with the increase of the operation period [1].

The total cost of purchased groups of spare parts analysis, conducted at the companies of material and technical support in the Russian Federation in 2016-2017, shows that the main part of them consists of engines and transmissions parts of tractors and self-moving agricultural machines, active parts of combine harvesters, tillage and sowing machines.

In order to reduce the costs, agricultural producers tend to purchase spare parts from alternative manufacturers, whose products do not always meet the quality level of the official manufacturer.

There are several types of alternative manufacturers:

- specialized companies-manufacturers of spare parts for agricultural machinery that have been engaged in this field for a long time and have extensive experience and established production technologies. Their products are of high quality;

- non-specialized spare part large machine-constructing companies, often included in the structure of the defense complex of the Russian Federation, enter this market to expand the production program in order to obtain additional profit. Often, these companies, having developed production capabilities, achieve high quality of their products;

- small companies that do not have significant production experience, advanced manufacturing technologies, as well as so-called "garage services" that have widely entered the spare part market recently. The quality of their products is often very poor, as a result of which spare parts of their production can be classified as counterfeit products;

- companies that do not have their own brand or disguise their products as products of another brand and often produce spare parts of extremely poor quality. The products of such enterprises can clearly be attributed to the "counterfeit" group [2].

The use of counterfeit products in all sectors of production, including agriculture, is significant and is estimated in monetary terms at about 2 billion USD [3]. At the same time, the share of 
counterfeit products is estimated by various sources at 9-30\% of total sales, depending on the type of spare parts.

To reduce the supply of low-quality spare parts, it is proposed to organize a quality control system for spare parts on the side of the dealer of agricultural machinery or spare parts for it. In this case, the problem of determining the composition of the control equipment and control parameters, such as sampling, number of measurements, etc., arises. This problem, in relation to the supply of spare parts for agricultural machinery, is poorly studied. There are no specific recommendations to determine both the parameters of the control process and its economic feasibility.

Thus, the aim of the study is to substantiate the methods of selecting tools and quality control modes for spare parts of agricultural machinery.

\section{Materials and methods}

To reach the research aim, an automated measuring device was created based on a laser triangulation scanner and sensor, a metal analyzer and a control system [4]. By the use of this device, a high level of automation of the process of input quality control of spare parts was achieved in experimental studies, which led to a significant reduction in the labor intensity of control.

The following parameters were used in the study:

- probability of a defect in a batch of parts $P_{\mathrm{D}}$ (the parameter is set in advance or determined for the batch by selecting a group of parts and monitoring them with an accurate device),

- probability of detecting a defect $P_{v d}$ when monitoring surfaces in several consecutive sections with a certain step (determined analytically, knowing the number of repetitions of the measurement $N$, length of the defective surface $L_{\mathrm{D}}$ and the total length of the controlled surface $L_{\mathrm{pov}}$.).

$$
P_{v d}=P_{b} \times \frac{L_{D}}{L_{p o v}} \times(N-1) \leq 1,
$$

where $P_{v d}$ - probability of detecting a defect;

$P_{\mathrm{b}}$ - probability of marriage;

$N$ - number of repetitions of measuring the surface of one part, units;

$L_{\mathrm{D}}$ - length of the defective surface, $\mathrm{mm}$;

$L_{\mathrm{pov}}-$ length of the controlled surface, $\mathrm{mm}$.

$P_{v d}$ values $>1$ suggest that the defect is guaranteed to be detected.

For comparison of contact and non-contact measuring instruments tests were conducted, in which for a fixed period of time in production conditions the control of spare parts of various manufacturers was carried out (JSC YAMZ, JSC TMZ, LLC Remdetal-Style, JSC Podolsky mechanical plant): parts of the cylinder-piston group of diesel engines YAMZ-236NM2 and spare parts of the agricultural pumping unit DNU-300/180, equipped with this engine (Fig. 1).

a)

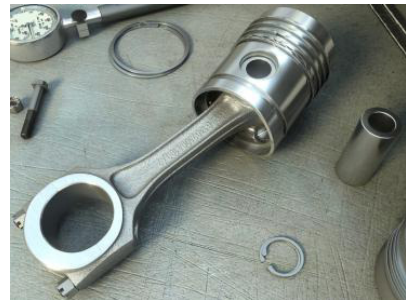

b)

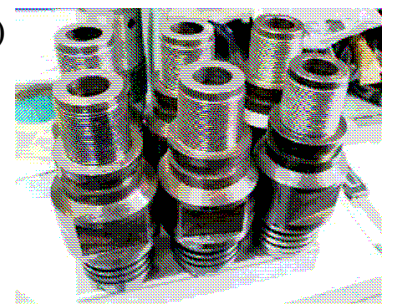

c)

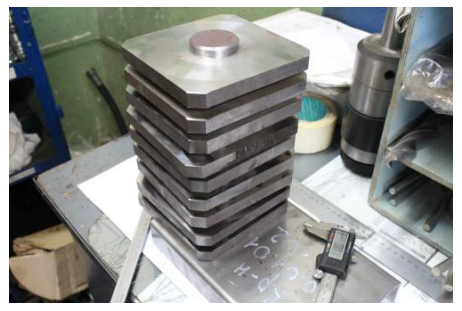

Fig. 1. Controlled spare parts: a - connecting rod and piston group YAMZ-236HM2; b - adapter122.21.00.00.008-02; c - insert 1222.05.08.00.001

\section{Results and discussions}

To determine the complexity of quality control of parts, the results of experimental studies of the outer diameter of the piston pin are taken.

The experiment revealed that even with the minimum performance of a non-contact measuring system of 1 prof $\cdot \mathrm{s}^{-1}$ and a part feed of $7.3 \mathrm{~mm} \cdot \mathrm{s}^{-1}$, the control of the finger surface with a length of 
$80 \mathrm{~mm}$ in two planes will take no more than $25 \mathrm{sec}$ during this time, 25 surface profiles will be monitored, which corresponds to a measurement step of $6.4 \mathrm{~mm}$ at the same time, a micrometer can make no more than 1-2 measurements. Thus, the performance of a non-contact measuring system in terms of monitoring frequency is more than 12 times higher than that of a mechanical contact measuring device.

The next experiment was aimed at determining the probability of detecting defects in the control of contact and automated non-contact measuring tools. A batch of 40 piston fingers was used, in which $95 \%$ of the samples had a violation of the geometry of the working surface, which is about $10 \%$ of its area. The surface profiles of the first three samples obtained as a result of control are shown in Fig. 2 and 3.

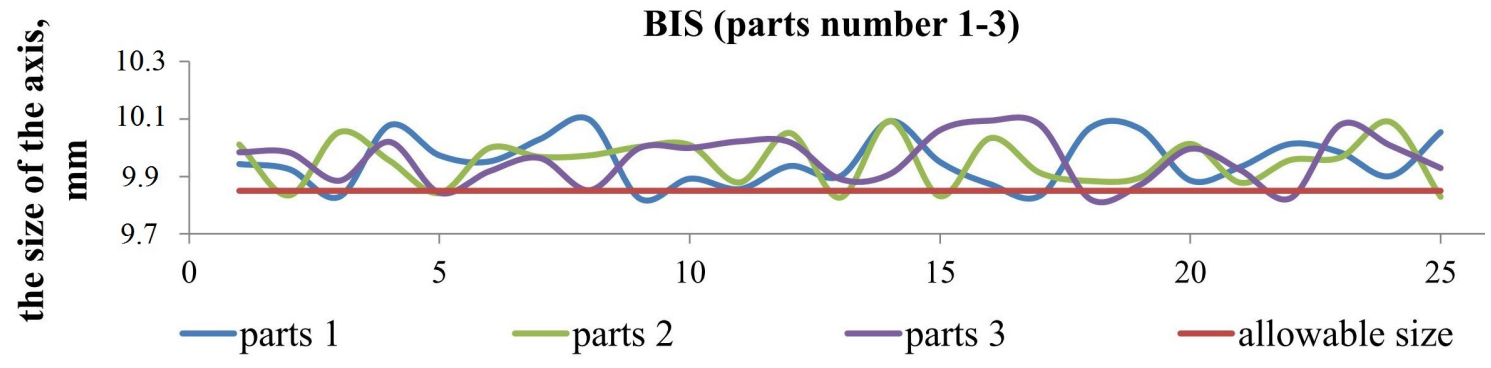

Measurement number

Fig. 2. Results of control of parts by non-contact measuring instruments

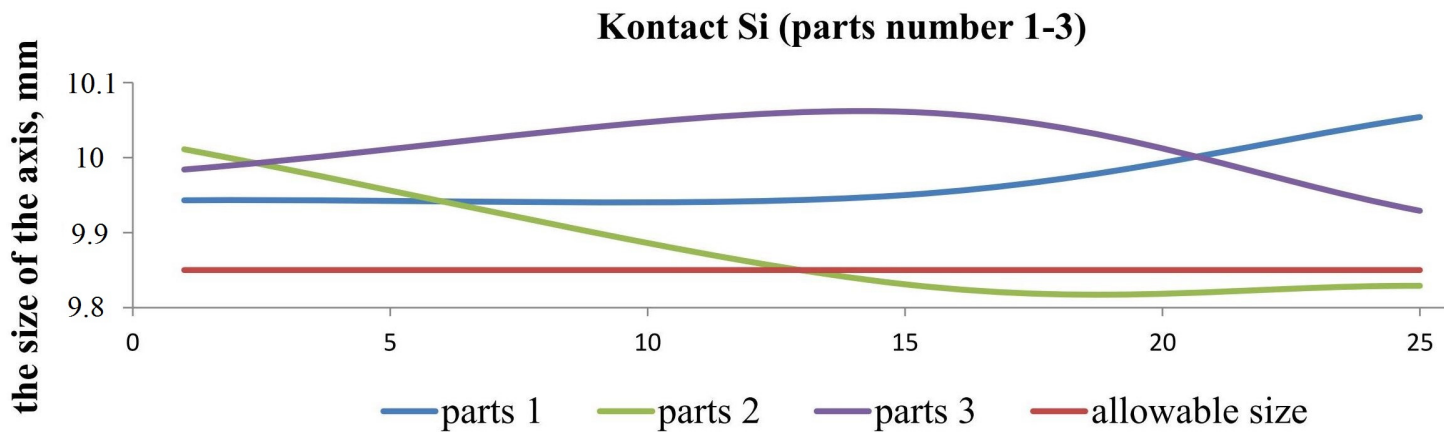

Measurement number

Fig. 3. Results of the control components of the contact measuring means

Analysis of the data obtained as a result of the experimental studies [5] showed that $18.7 \%$ of defects were detected in the batch using contact measuring instruments (MK 50 micrometer) against $95 \%$ for non-contact measurements.

The calculation of the dependence 1 shows that the theoretical value of the probability of detecting a defect for contact SI is $P_{\mathrm{vd}}=0.19$, for non-contact $P_{\mathrm{vd}}=0.95$, which corresponds to the experimental value of the parameter.

We introduce the concept of defect vastness, which shows the percentage ratio of the length of the defective area and the controlled surface

$$
P_{o d}=\frac{L_{D}}{L_{p o v}}
$$

where $P_{o d}$ - vastness of the defect.

In order to guarantee the detection of a defect of a certain extent, it is necessary to observe the following condition $P_{v d}=1 ; P_{\mathrm{b}} \neq 0 ; \mathrm{P}_{\mathrm{od}} \neq 0$. The number of measurements is determined as follows:

$$
N=\frac{1}{P_{b} \times P_{o d}} \text {, units }
$$


Table 1 and the graph (Fig. 4) show the dependence of the required number of measurements of one part to detect a defect on the extent of the defect and the probability of marriage.

Table for determining the required number of measurements

Table 1

\begin{tabular}{|c|c|c|c|c|c|c|c|c|c|c|c|}
\hline \multirow{2}{*}{$\begin{array}{l}\text { Vastness of } \\
\text { the defect }\end{array}$} & \multicolumn{11}{|c|}{ Required number of measurements for the probability of defect } \\
\hline & 0.05 & 0.1 & 0.2 & 0.3 & 0.4 & 0.5 & 0.6 & 0.7 & 0.8 & 0.9 & 1 \\
\hline 0.05 & 400 & 200 & 100 & 67 & 50 & 40 & 34 & 29 & 25 & 23 & 20 \\
\hline 0.1 & 200 & 100 & 50 & 34 & 25 & 20 & 17 & 15 & 13 & 12 & 10 \\
\hline 0.2 & 100 & 50 & 25 & 17 & 13 & 10 & 9 & 8 & 7 & 6 & 5 \\
\hline 0.3 & 67 & 34 & 17 & 12 & 9 & 7 & 6 & 5 & 5 & 4 & 4 \\
\hline 0.4 & 50 & 25 & 13 & 9 & 7 & 5 & 5 & 4 & 4 & 3 & 3 \\
\hline 0.5 & 40 & 20 & 10 & 7 & 5 & 4 & 4 & 3 & 3 & 3 & 2 \\
\hline 0.6 & 34 & 17 & 9 & 6 & 5 & 4 & 3 & 3 & 3 & 2 & 2 \\
\hline 0.7 & 29 & 15 & 8 & 5 & 4 & 3 & 3 & 3 & 2 & 2 & 2 \\
\hline 0.8 & 25 & 13 & 7 & 5 & 4 & 3 & 3 & 2 & 2 & 2 & 2 \\
\hline 0.9 & 23 & 12 & 6 & 4 & 3 & 3 & 2 & 2 & 2 & 2 & 2 \\
\hline 1 & 20 & 10 & 5 & 4 & 3 & 2 & 2 & 2 & 2 & 2 & 1 \\
\hline
\end{tabular}

$\square-50 \square 50-100 \square 100-150 \square 150-200 \quad 200-250 \square 250-300 \quad 300-350 \square 350-400$

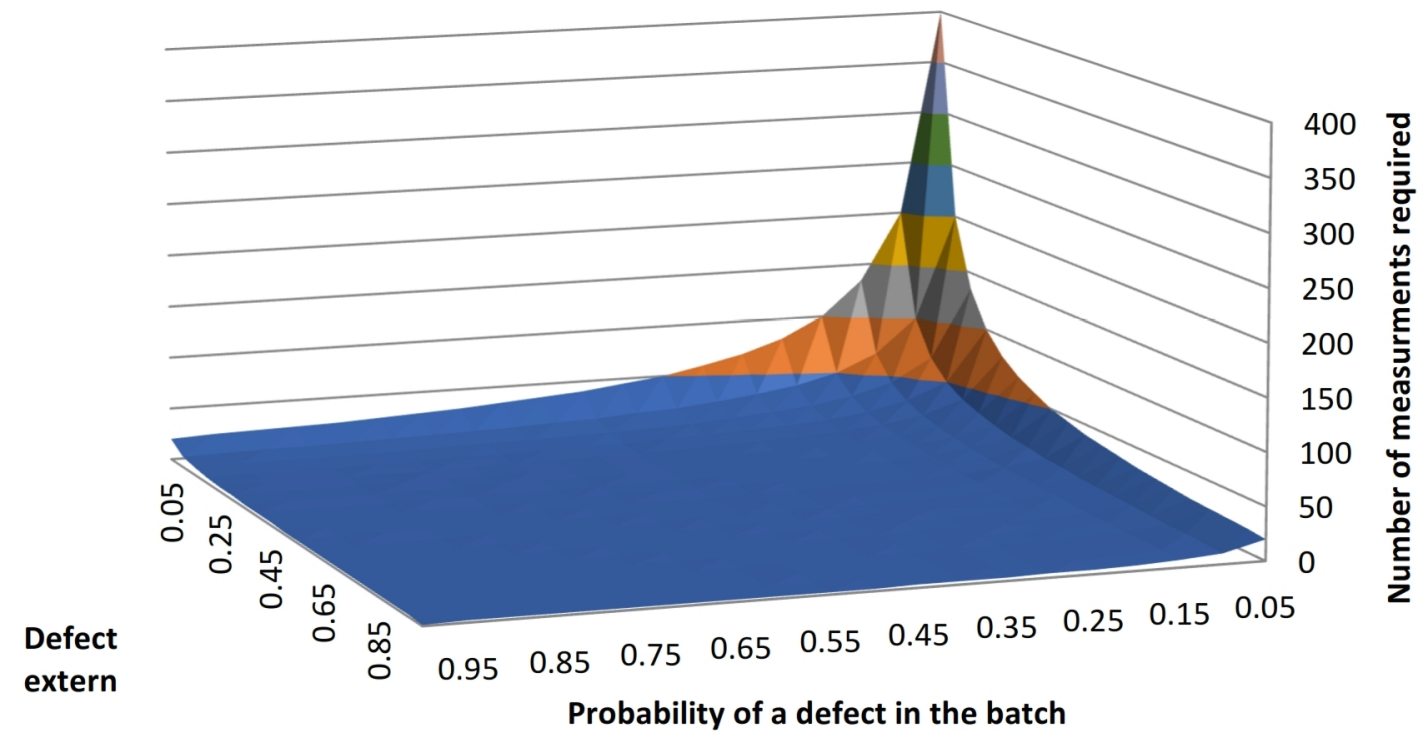

Fig. 4. Dependence of the required number of measurements on the vastness of the defect and the probability of defect

Table 1 shows the zone of effective use of mechanical contact measuring devices. As it can be seen from the table, the feasibility of using mechanical contact measuring devices is limited by a high (more than $50 \%$ ) probability of failure and significant (also more than $50 \%$ ) defect sizes.

As part of the experiment, the labor intensity of monitoring by mechanical contact and noncontact measuring devices was determined.

For the experiment, the main devices used for input control of geometric parameters of machinebuilding products were used. The experiments were conducted under laboratory conditions by an experienced controller.

The complexity of the control was determined by timing. The time spent on checking one size, calibration, adjustment to a new size, and reinstalling the device or the controlled item in the device was recorded. For comparison, data from other measurement tools are provided.

The timing data are shown in Table 2. 
Timing data for the measurement process

\begin{tabular}{|c|c|c|c|c|c|c|c|}
\hline $\begin{array}{l}\text { Name of the measuring } \\
\text { instrument }\end{array}$ & 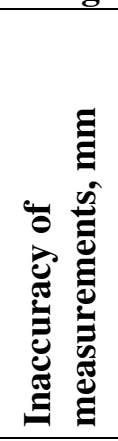 & 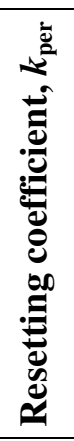 & 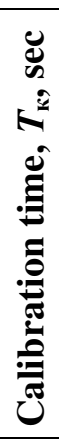 & 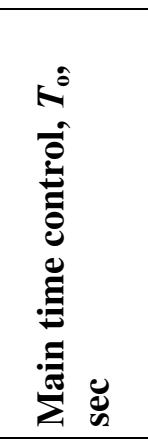 & 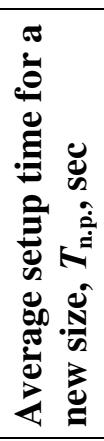 & 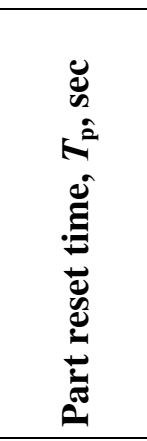 & 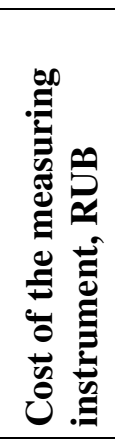 \\
\hline $\begin{array}{l}\text { Micrometer MK50 } \\
\text { GOST 6507-90 }\end{array}$ & 0.002 & 1 & 40 & 10 & 13 & 7 & 850 \\
\hline $\begin{array}{l}\text { Micrometer MK250 } \\
\text { GOST 6507-90 }\end{array}$ & 0.004 & 1 & 40 & 9 & 13 & 8 & 1850 \\
\hline $\begin{array}{l}\text { Micrometer Digimatic } \\
\text { QuantuMike IP65 } \\
\text { Mitutoyo } 293\end{array}$ & 0.001 & 1 & 20 & 5 & 7 & 3 & 13497 \\
\hline $\begin{array}{l}\text { Calliper ШЦ-1-125 } \\
\text { GOST 166-89 }\end{array}$ & 0.1 & 1 & - & 8 & - & 3 & 92 \\
\hline $\begin{array}{l}\text { Digital Calliper ШЦЦ-1- } \\
125 \\
\text { GOST 166-89 }\end{array}$ & 0.05 & 1 & - & 5 & - & 3 & 300 \\
\hline $\begin{array}{l}\text { Gauge-bracket 8118- } \\
0008 \text { GOST 2216-84 }\end{array}$ & 0.002 & 1 & 40 & 2 & - & 2 & 975 \\
\hline $\begin{array}{l}\text { Caliper 100-160 } \\
\text { GOST 9244-75 }\end{array}$ & 0.018 & 3 & 25 & 3 & 25 & 4 & 16960 \\
\hline $\begin{array}{l}\text { Goniometer type } 1-2 \\
\text { GOST 5378-88 }\end{array}$ & $1 "$ & 2 & - & 8 & - & $3-6$ & 2419 \\
\hline $\begin{array}{l}\text { Contactless measuring } \\
\text { system БИС Т-200 (high } \\
\text { performance) }\end{array}$ & 0.02 & 3 & 10 & 0.00015 & 3 & $\begin{array}{c}\text { profile } \\
0.00027 \\
\text { part } 7\end{array}$ & $\begin{array}{l}1.2 \\
\text { mln. }\end{array}$ \\
\hline $\begin{array}{l}\text { Contactless measuring } \\
\text { system БИС Т-200 (high } \\
\text { accuracy) }\end{array}$ & 0.005 & 3 & 10 & 0.00077 & 3 & $\begin{array}{l}\text { profile } \\
0.1536 \\
\text { part } 7 \\
\end{array}$ & $\begin{array}{c}1.2 \\
\mathrm{mln}\end{array}$ \\
\hline
\end{tabular}

The complexity of the control of the part details:

$$
T=T_{K}+N_{D}\left(T_{o}+\sum N_{k i}+T_{p e r}+T_{n . p . .} \times k_{p e r}\right), \mathrm{s} .
$$

where $T_{K}$-complexity of calibration, s;

$T_{o}$ - complexity of a single measurement/control of a single profile, $\mathrm{s}$;

$N_{k i}$ - number of profiles required to control the $i$-th surface of the part, units;

$N_{D}$ - volume of the batch of parts, units;

$T_{p e r}-$ difficulty of part reinstalling, s;

$T_{\text {n.p. }}-$ complexity of changing to a new size, s;

$K_{\text {per }}-$ resetting coefficient.

For non-contact measuring instruments

$$
T_{\text {per. }}=T_{\text {per.p. }} \times \sum N_{\kappa i}+T_{\text {per.d }}, \mathrm{s},
$$

For contact measuring instruments

$$
T_{p e r .}=T_{p}\left(\sum N_{\kappa i}+1\right), \mathrm{s},
$$

where $T_{\text {per.p. }}-$ complexity of resetting a part to a new profile, s; 
$T_{\text {per.d. }}-$ difficult of part reinstalling, s;

$T_{\mathrm{p}}$ - complexity of reinstalling for monitoring contact SI, s.

The permutation coefficient is determined according to Figure 5.

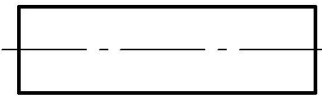

$k_{\text {per }}=1$

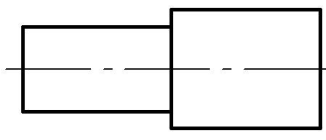

$k_{\text {per }}=2$

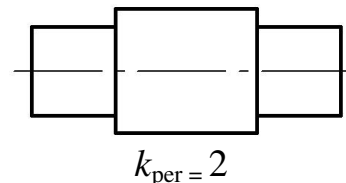

$k_{\mathrm{per}}=2$

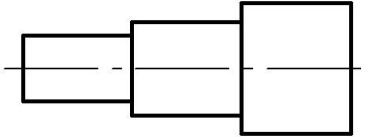

$k_{\text {per }}=3$

Fig. 5. Determining the reset rate

Let us compare the results of monitoring by contact and non-contact measuring tools. To do this, we will determine the cost of control of $\mathrm{C}_{\mathrm{K}}$, rubles, depending on the labor intensity.

$$
C_{\kappa}=\left(\frac{Z_{\kappa}}{3600}+\frac{C_{0}}{36000 \times t_{a} \times F_{N O}}\right) \times T, \mathrm{RUB},
$$

where $Z_{\mathrm{K}}-$ controller's hourly tariff rate, RUB;

$C_{0}$ - cost of the equipment, RUB;

$t_{\mathrm{a}}$ - depreciation period, years;

$F_{\mathrm{NO}}-$ nominal annual fund of equipment time, h;

$T$ - labor intensity of control of a batch of parts, s.

$$
F_{N O}=\left[\left(d_{k}-d_{v}-d_{p}\right) \times t_{c}-d_{p p} \times\left(t_{c}-t_{s p p}\right)\right\rfloor \times n, \mathrm{~h},
$$

where $d_{\mathrm{k}}-$ number of calendar days per year;

$d_{\mathrm{b}}$ - number of days off per year;

$d_{\mathrm{p}}$ - number of public holidays per year;

$d_{\mathrm{pp}}-$ number of pre-holiday days per year;

$t_{\mathrm{c}}$ - duration of the change, $\mathrm{h}$;

$t_{\mathrm{spp}}-$ shift duration on a pre-holiday day, h;

$n$ - number of shifts.

$$
F_{N O}=[(365-52-12) \times 8-4 \times 1] \times 1=2404, \mathrm{~h} .
$$

As an object of comparison, we will take 100 parts of the "shaft" type, which have three successively increasing stages in diameter $\left(k_{\mathrm{per}}=3\right) P_{\mathrm{b}}=0,4, P_{\mathrm{od} 1}=0,6, P_{\mathrm{od} 2}=0,15, P_{\text {od } 3}=0,1$.

The results of calculating the cost of controlling a single part are presented as a graph (Fig. 6).

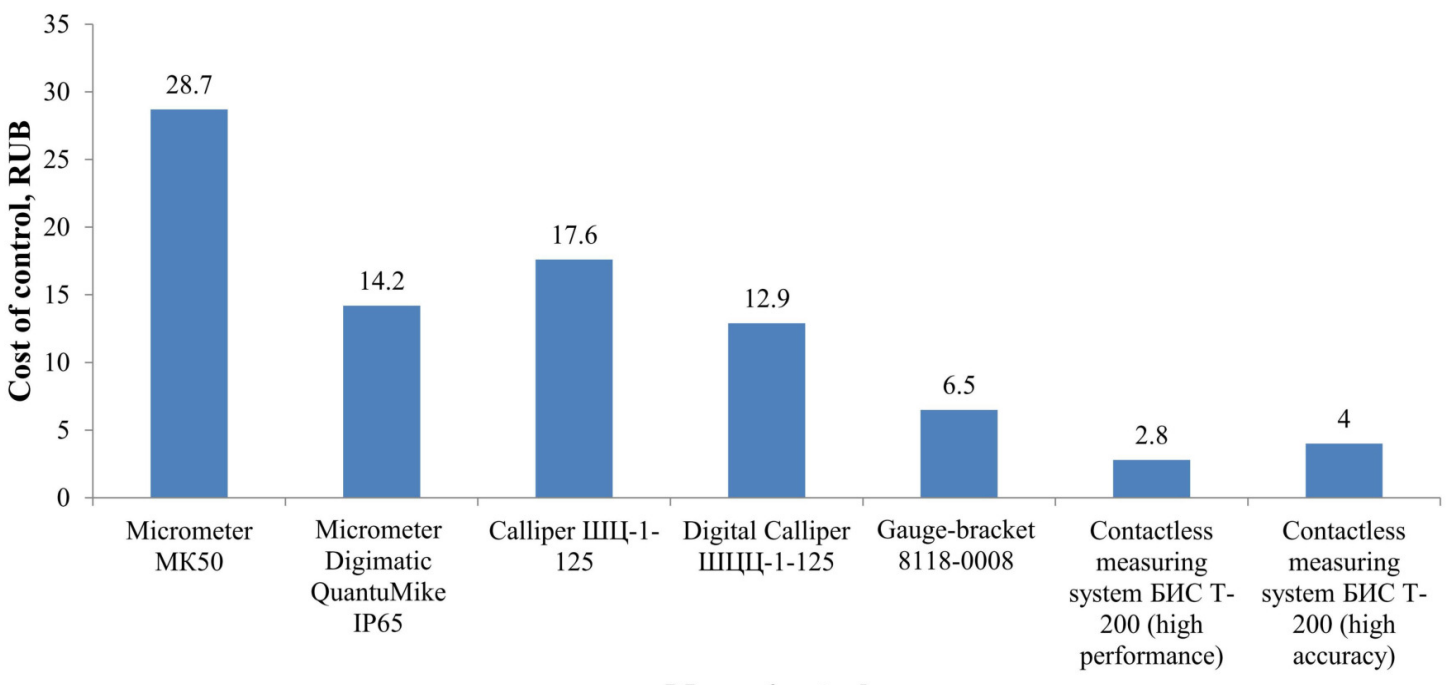

Measuring tool

Fig. 6. Results of comparing the cost of monitoring the external surface of the part

The contactless measuring system is completed on the principle of achieving maximum accuracy and performance, while maintaining the affordability of control and measuring equipment. 


\section{Conclusions}

1. Measuring tasks of low complexity, characterized by low repeatability, are solved with less cost by contact mechanical devices;

2. More complex measurement tasks requiring high performance and high repeatability are solved with less cost by automated optoelectronic contactless systems;

3. The cost of monitoring by a contactless measuring system within the specified limits is significantly lower than the same indicator of a contact mechanical measuring device. When the speed of automated optoelectronic contactless systems increases, the accuracy and cost of control decrease.

\section{References}

[1] Van der Auweraer S., Boute R. Forecasting spare part demand using service maintenance information. International journal of production economics No.213, 2019, pp. 138-149.

[2] Вельш П.Г. Проблема разграничения терминов “контрафактная продукция" и “альтернативные производители" при раскрытии и расследовании (The Problem of distinguishing the terms ,,counterfeit products” and ,alternative manufacturers” in the detection and investigation of crimes). Bulletin of the Vladimir law Institute, 2011. No. 3 (20). pp. 74-76. (In Russian).

[3] Крылов А.А. Структура и масштабы незаконного оборота промышленной продукции в рамках Евразийского экономического союза (ЕАЭС) (Structure and scale of illegal turnover of industrial products within the framework of the Eurasian economic Union (EEU)). Microeconomics. 2017. No 5. pp. 67-74. (In Russian).

[4] Automated device for quality control of spare parts: Pat. 175415 ROS. Federation: IPC G01B 11/03 / S. Dorokhov, K. A. Krasnyashchikh, Yu. V. Kataev, D. M. Skorokhodov; applicant and patent holder of the Timiryazev Moscow state agricultural Academy - no. 2017116420; 11.05.2017; publ. 04.12.17. Bull. No 34. - 5 pp (In Russian).

[5] Дорохов А.С., Краснящих К.А., Скороходов Д.М. Система контроля качества деталей сельскохозяйственных машин (Quality control system of agricultural machinery parts). Moscow: MESKH, 2019. 192 p. (In Russian). 